IZA DP No. 4284

The Impact of a Phased Retirement Program:

A Case Study

Marta Lachowska

Annika Sundén

Eskil Wadensjö

July 2009 


\title{
The Impact of a Phased Retirement Program: A Case Study
}

\author{
Marta Lachowska \\ SOFI, Stockholm University
}

Annika Sundén

SOFI, Stockholm University

\author{
Eskil Wadensjö \\ SOFI, Stockholm University \\ and IZA
}
Discussion Paper No. 4284
July 2009

IZA
P.O. Box 7240
53072 Bonn
Germany

Phone: $+49-228-3894-0$

Fax: +49-228-3894-180

E-mail: iza@iza.org

\begin{abstract}
Any opinions expressed here are those of the author(s) and not those of IZA. Research published in this series may include views on policy, but the institute itself takes no institutional policy positions.

The Institute for the Study of Labor (IZA) in Bonn is a local and virtual international research center and a place of communication between science, politics and business. IZA is an independent nonprofit organization supported by Deutsche Post Foundation. The center is associated with the University of Bonn and offers a stimulating research environment through its international network, workshops and conferences, data service, project support, research visits and doctoral program. IZA engages in (i) original and internationally competitive research in all fields of labor economics, (ii) development of policy concepts, and (iii) dissemination of research results and concepts to the interested public.
\end{abstract}

IZA Discussion Papers often represent preliminary work and are circulated to encourage discussion. Citation of such a paper should account for its provisional character. A revised version may be available directly from the author. 


\section{ABSTRACT}

\section{The Impact of a Phased Retirement Program: A Case Study}

Phased retirement has been discussed as a means for increasing labour supply for people of older active age. The idea is that instead of leaving a full-time job early for full-time retirement, an employee should reduce the working time either in the same job or by changing jobs, and stay on in the labour market. In this paper we analyze the factors that influence the decision to take up a part-time pension and continue working at the same work place at reduced hours. We do this by using a unique data set from one employer in the governmental sector in Sweden, Stockholm University. The pension scheme is a special parttime pension scheme introduced for state employees in 2003. Employees 61 years and older can apply for a part-time pension up to the age of 65 . The employers decide if they will accept or reject the application. They may also encourage employees to apply or discourage them from doing so. We have a data set covering all employees of the age groups who are eligible and a rich data set with information on the employees and also on the units (departments) who in practice decide if an application should be accepted or not. We find that both the effects on pension wealth of taking a part-time pension, and the economic situation of the department are important for the propensity for becoming a part-time pensioner. Also individual characteristics such as gender, age, earnings and occupation are important.

JEL Classification: H55, J22, J26, J14

Keywords: part-time work, part-time pension, older workers, labour supply

Corresponding author:

Eskil Wadensjö

Swedish Institute for Social Research (SOFI)

Stockholm University

SE-10691 Stockholm

Sweden

E-mail: eskil.wadensjo@sofi.su.se 


\section{Introduction}

The role of pension systems is of current interest in a Western Europe that is facing an ageing population. Many attempts have been made to raise the age of retirement. One policy that has been tested in several countries is to offer greater flexibility for the worker by introducing a possibility of phased retirement with a favourable part-time pension option.

Sweden has tested different part-time pension schemes. Since the early 1960s it has been possible to take out part of the old-age pension before the normal retirement age, or postpone it. In such case the pension has been actuarially reduced or augmented, respectively. From 1976 to 2000 a special part-time pension was in force for those aged 60-64 (in 1994 changed to 61-64). ${ }^{1}$ A take-up of such a pension did not reduce the old age pension taken out at 65 . In 2001-2002 no special part-time pension option existed. However, in 2003 a special part-time pension system was introduced for those employed by the central government and in 2007 a scheme for those employed by local government (municipalities and county councils) was introduced.

In this paper we study the effects of the part-time pension scheme for employees in the central government. The data set at our disposal is employees at Stockholm University who have either entered the phased retirement option, have remained fully employed or have ended their employment in some other way. Stockholm University is a state university with more than 5000 employees. This sample is not representative of the working population in Sweden of course, but has a great advantage by the richness of information it provides in describing characteristics of the individuals as well as modelling ways out of employment.

Although there is a great interest in part-time pensions in many countries, there has not been much research on it. $^{2}$ Most studies are based on macro indicators and not on individually based panel studies, which in most cases would be the preferred form. Sundén (1994) studies the Swedish special part-time pension scheme by using a Swedish panel data base and examines what those who take a part-time pension would have done instead - continued to work full time or take an early full time disability pension. The results from this study have been combined with information on the actual hours worked before and after taking a part-

\footnotetext{
${ }^{1}$ See Ginsburgh (1985), Wadensjö $(1993,1996)$ and Wise (1990) for some presentations of that system.

${ }^{2}$ See the various contributions in Delsen \& Reday-Mulvey (1998), and Latulippe \& Turner (2000) for surveys of the international experiences. There are a number of papers that analyze phased retirement in the US. See for example Chen (2002), Chen and Scott (2003), Clark (2002), Even and Macpherson (2004), Ponner, Perun and Steuerle (2002), Scahill and Forman (2002) and Wong (2002).
} 
time pension to calculate the labour supply effect (see Wadensjö, 2006a and b, and Lachowska, Sundén and Wadensjö, 2008).

A study of much relevance for our study has examined the effects of the introduction of a part-time pension scheme at one of the campuses of the University of North Carolina (see Allen, 2004 and Allen, Clark and Ghent, 2004). The results indicate that the share who retires increased after the introduction of the system. The increase in the share who retires is however less than the share who accepted a part-time pension. This means that of those taking up a part-time pension some would have continued to work full-time and some would have been full-time pensioners. The study also tries to answer the question of what characterizes those who became part-time pensioners. It shows that the part-time pensioners are more similar to those who continue to work full-time than those who become full-time pensioners.

\section{Phased retirement in the governmental occupational pension system}

Since 2003, the occupational agreement allows the employees in the state sector to apply for a part-time pension. The rules allowing entrance to the phased retirement program are the following:

- Phased retirement can be offered to individuals starting the month they turn 61 years of age and at the latest until turning 65 years of age

- The individual must have been entitled, for at least 120 months, to a retirement plan that has been negotiated through a collective agreement

- Phased retirement option can, at most, amount to 50 per cent of full-time employment

- The phased retirement benefit corresponds to 60 per cent of the wage lost due to the decrease in hours, but the size of the phased retirement benefits changes proportionally to changes in the wage

- The employer can accept or reject an application for a part-time pension

- Phased retirement in the state sector is financed by the employer, who pays a 24.26 per cent tax on the phased retirement benefit.

Table 1 shows the number of newly accepted phased retirements over the years 2003-2007 in the state sector. Most have been granted a phased retirement of 20 percent of full-time work, followed by 50 percent in the early years 2003 and 2004. Women more often take up a 20 per 
cent part-time pension, men more often a 50 per cent part-time pension. It is not possible to conclude from the statistics if the development in the direction towards 20 per cent pensions is due to that the employees want it (free on Fridays or shorter workdays) or due to that the employers for financial reasons do not accept other forms of part-time pensions. Most of those who are granted a part-time pension are 61 years of age, i.e. the lowest possible age.

Table 1 New phased retirees per year in 2003-2007

\begin{tabular}{lcccccc}
\hline & \multicolumn{5}{c}{ Year } & \multirow{2}{*}{ Total } \\
\cline { 2 - 6 } Scope & $\mathbf{2 0 0 3}$ & $\mathbf{2 0 0 4}$ & $\mathbf{2 0 0 5}$ & $\mathbf{2 0 0 6}$ & $\mathbf{2 0 0 7}$ & \\
\hline $\mathbf{2 0} \%$ or less & 719 & 680 & 895 & 1000 & 1212 & 4506 \\
$\mathbf{2 1 - 4 9} \%$ & 352 & 259 & 279 & 288 & 267 & 1445 \\
$\mathbf{5 0} \%$ & 956 & 798 & 662 & 570 & 559 & 3545 \\
\hline Total & 2027 & 1737 & 1836 & 1858 & 2038 & 9496 \\
\hline
\end{tabular}

Source: SPV, Pensionsavgångar inom statsförvaltningen, Kommentarer, Bilaga 2. 2007-02-28 and SPV, Statliga pensioner - trender och tendenser, Dnr: 2008-3111-76.

In practice it is possible to combine one's employment and phased retirement with outside work. Thus it is possible for example to be employed half-time in the state sector, be retired half-time and be employed half-time outside the state sector. ${ }^{3}$

Studies conducted on the effects of pension systems on an individual's retirement decision often do not model the financial situation of the employer. In the case of phased retirement at Stockholm University the inclusion of such a variable is desirable. At Stockholm University, the department (or a corresponding unit) pays 25 per cent of the costs, while the University pays the remaining 75 per cent. As the phased retirement benefit is computed to be 60 per cent of the wage that vanish due to the decrease in hours, the department pays only 25 per cent of that cost itself. Thus the cost incurred for the department is 15 per cent of the wage

\footnotetext{
${ }^{3}$ According to the agreement there are no restrictions. The instructions given by The Swedish Agency for Government Employers (Arbetsgivarverket, 2002) state however that it is not allowed to work during hours with part time pension. And that the local employer should verify that the employee fulfils this condition but that the employer could give the employee the right to work to a minor extent. According to information we have received quite a few part-time pensioners are working during the same hours for which they receive part-time pension. See Mårtensson (2005).
} 
paid to the phased retiree. Hence it can be argued that phased retirement is a relatively cheap option for the direct employer to cut down on costs if they get a budget cut.

The presentation of the part-time pension system shows that it is important to have data both on the employees who are eligible to apply for a part-time pension and for the units who may accept or reject the applications. In the next section we will present the data and variable used.

\section{Data}

The data originate from the Personnel Administrative Office at the Stockholm University. The data are comprised of the set of phased retirees in the years 2003-2006, and a set of employees eligible for applying for phased retirement in the same period. The data sets contain information on personal characteristics such as age and gender. ${ }^{4}$ Further, the data include rich information on employment characteristics; department, institution and faculty affiliation, position held, form of employment, length of service in the state sector as well as at Stockholm University, working hours in relation to full-time employment, retirement plan type, and the scope of the phased retirement as a part of full-time employment and reasons for changing or ending employment. Information regarding annual wage payments for the years 2003-2006 is also available.

The data were matched with information retrieved from the annual accounts done by the administrative units at the University for the years 2002-2005. This set contained variables such as

- total revenue

- annual capital gain

- balance brought forward/capital gain brought from last year and

- balance carried forward/total capital gain

\subsection{Individual characteristics}

The information from the accounts reveals that some individuals have several channels of payment. The most common reason for that was that a person held several positions in parallel, e.g. as a lecturer and as a researcher and hence had two sources of income that year.

\footnotetext{
${ }^{4}$ For a full description of the variables, see the Appendix 1
} 
In some cases, individuals had changed their form of employment within the department and in rare cases between departments (no one had switched faculty affiliation). As the size of the sample allows for examining those cases in turn (the number of individuals with this type amounted to 64 individual cases), an analysis followed. The annual payments for those individuals were summed over each year, so was the share of employment (in most cases this added up to 100 per cent). Regarding the indicators of position held, form of employment and department affiliation, the most recent position and department were selected for the individual. In a great majority of cases the positions that were held in parallel did not suggest that a great change in the duties performed was present.

Arranging the merged data eventually produced a set of 314 individuals that provided information on the individuals in the manner of a pooled cross-section running over the years 2003-2006. Although the same individual may appear in the data in several years, each yearly observation of an individual is treated as a distinct observational unit.

A scrutiny of the structure of the data followed and indicators of time of exiting the data set, or making the choice of gradually retiring were created. ${ }^{5}$ The complete data set comprises 1,154 observations across the years 2003 until 2006, where certain individuals appear in all the four years or three years and some in two and a few only once (i.e. those who had exited employment at Stockholm University the first year they are observed).

In Table 2 summary statistics of characteristics of those who have chosen the phased retirement option and those who were eligible at a given year to apply but did not are presented. We see that there are slightly more men than women in the population studied. The age categories range between 61 years to 65 years in 2006 as only those in that age group are eligible for a part-time pension. About 28 per cent of the full sample have been granted a parttime pension.

\footnotetext{
${ }^{5}$ As the individuals entered or exited the retirement options at different dates of the year, but the payments are reported on an annual basis, we made the simplification of rounding the date off downwards to the year that the individual made his/her choice.
} 
Table 2 Summary Statistics

\begin{tabular}{|c|c|c|c|c|c|c|c|}
\hline Variable & Mean & Sd & p50 & Min & Max & Range & $\mathbf{N}$ \\
\hline \multicolumn{8}{|l|}{ Phased and eligible } \\
\hline Woman & .449 & .498 & 0 & 0 & 1 & 1 & 1154 \\
\hline Age & 62.29 & 1.16 & 62 & 61 & 65 & 4 & 1154 \\
\hline Phased & .279 & .449 & 0 & 0 & 1 & 1 & 1154 \\
\hline $\begin{array}{l}\text { Working hours/full-time } \\
\text { hours }\end{array}$ & 98.29 & 7.39 & 100 & 50 & 100 & 50 & 1154 \\
\hline Length at SU & 24.52 & 11.48 & 26 & 0 & 46 & 46 & 1154 \\
\hline Earnings/10 000 & 36.78 & 15.63 & 34.93 & 0 & 107.6 & 107.6 & 1154 \\
\hline \multicolumn{8}{|l|}{ Phased } \\
\hline Woman & .581 & .494 & 1 & 0 & 1 & 1 & 322 \\
\hline Age & 62.71 & 1.29 & 63 & 61 & 65 & 4 & 322 \\
\hline Phased & 1 & 0 & 1 & 1 & 1 & 0 & 322 \\
\hline $\begin{array}{l}\text { Working hours /full- } \\
\text { time hours }\end{array}$ & 97.82 & 9.10 & 100 & 50 & 100 & 50 & 322 \\
\hline Length at SU & 25.13 & 11.19 & 26 & 2 & 44 & 42 & 322 \\
\hline Earnings/10 000 & 28.36 & 10.18 & 27.61 & 0 & 64.5 & 64.5 & 322 \\
\hline \multicolumn{8}{|l|}{ Eligible } \\
\hline Woman & .398 & .490 & 0 & 0 & 1 & 1 & 832 \\
\hline Age & 62.13 & 1.05 & 62 & 61 & 64 & 3 & 832 \\
\hline Phased & 0 & 0 & 0 & 0 & 0 & 0 & 832 \\
\hline $\begin{array}{l}\text { Working hours/full-time } \\
\text { hours }\end{array}$ & 98.47 & 6.61 & 100 & 55 & 100 & 45 & 832 \\
\hline Length at SU & 24.28 & 11.59 & 26 & 0 & 46 & 46 & 832 \\
\hline Earnings/10 000 & 40.04 & 16.16 & 39.03 & 0 & 107.6 & 107.6 & 832 \\
\hline
\end{tabular}

Source: Calculations based on data for Stockholm University for 2003-2006.

We note that a higher share of the female employees than of the male employees have chosen the phased retirement option. As a result of the rules for entering the option, the eligible subsample is the same age as the phased retirees. The table shows that the youngest age of a phased pensioner in this sample is 61 years, while the most senior is 65 . This is due to rounding among the individuals, who may have entered the phased retirement option in the middle of the year that they turned 65 . We note that the share of full-time employment is similar, but that the variance is higher for the phased retirees.

We have looked at the ways the phased retirees exited our sample. About 77 per cent, or 34 individuals of the sample had retired - the other options consisted of early old-age retirement (not shown here).

Turning instead to the duration of position held one notes that phased retirees have a similar higher tenure, about 24 years, on average as the eligible sample. 
Another variable describing the characteristics of the individuals who chose phased retirement is the scope of the phased retirement, see the figure below. A clear majority have chosen a half-time phased retirement option, and then followed by 20 per cent and 40 per cent.

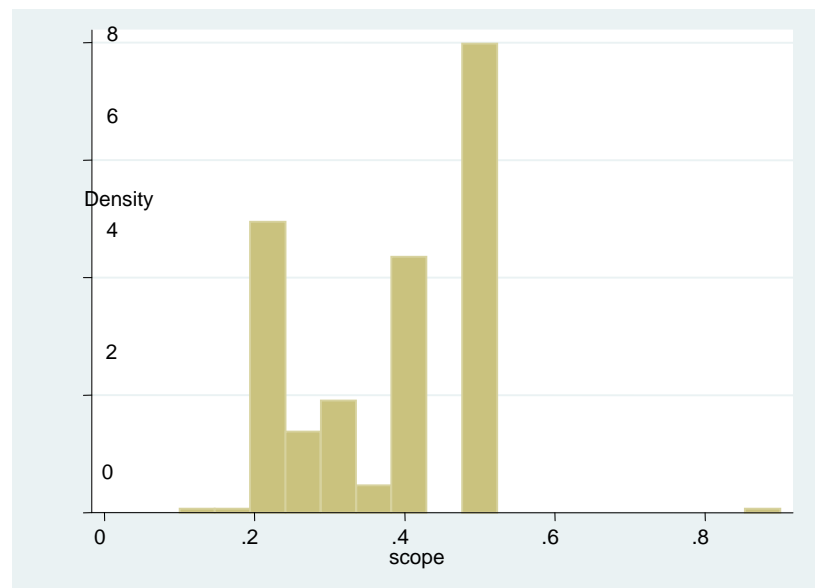

Figure 1 Percentage distribution of scope of the part-time pensions

It is interesting to see where the phased retirees work; we can do this by analyzing faculty affiliation and also what positions these individuals hold. The Faculty of Natural Sciences has the largest share phased retirees, followed by the Faculty of Social Sciences. See Table 3. Among the eligible who have not received a part-time pension, the Faculty of Social Sciences employed the largest part, followed by the Faculty of Natural Sciences.

Table 3 Faculty Affiliation

\begin{tabular}{lcllcll}
\hline & \multicolumn{3}{c}{ Phased } & \multicolumn{3}{c}{ Eligible } \\
\cline { 2 - 7 } Faculty & Freq & Per cent & Cum & Freq & Per cent & Cum \\
\hline Administration & 48 & 14.91 & 14.91 & 54 & 6.49 & 6.49 \\
Humanities & 47 & 14.60 & 29.50 & 205 & 24.64 & 31.13 \\
Law School & 3 & 0.93 & 30.43 & 27 & 3.25 & 34.38 \\
Natural Sciences & 104 & 32.30 & 62.73 & 218 & 26.20 & 60.58 \\
Social Sciences & 99 & 30.75 & 93.48 & 275 & 33.05 & 93.63 \\
University library & 21 & 6.52 & 100 & 53 & 6.37 & 100 \\
\hline Total & 322 & 100 & & 832 & 100 & \\
\hline
\end{tabular}

Source: Calculations based on data for Stockholm University for 2003-2006. 
Our data set allows us to see what positions the individuals hold; this indicator suffers, however, from being largely titular and not fully reflecting the occupation of the individual in question. Instead, we have grouped these titles into five occupational categories: strenuous work $^{6}$, lower administrative personnel, higher administrative personnel, researcher/professor, and lecturer. We see that the phased retirees mainly belong to the higher administrative personnel category. Also for the entire sample, the category 'Higher Administrative Personnel' is the largest with 46 per cent, followed by 'Researcher/Professor'. See Table 4.

Table 4 Occupational categories

\begin{tabular}{lllllll}
\hline \multirow{2}{*}{ Occupational categories } & \multicolumn{3}{c}{ Phased } & \multicolumn{3}{c}{ Eligible } \\
\cline { 2 - 7 } & Freq & Per cent & Cum & Freq & Per cent & Cum \\
\hline Strenuous work & 6 & 1.86 & 1.86 & 10 & 1.20 & 1.20 \\
Lower Administrative Staff & 54 & 16.77 & 18.63 & 72 & 8.65 & 9.86 \\
Higher Administrative Staff & 180 & 55.90 & 74.53 & 381 & 45.79 & 55.65 \\
Researcher/Professor & 28 & 8.70 & 83.23 & 241 & 28.97 & 84.62 \\
Lecturer & 54 & 16.77 & 100.00 & 128 & 15.38 & 100.00 \\
\hline Total & 322 & 100.00 & & 832 & 100.00 & \\
\hline
\end{tabular}

Source: Calculations based on data for Stockholm University for 2003-2006.

\subsection{Computation of the Incentive Measures}

The pensions depend on the earnings history of the individual. We lack information on the earnings histories in our data set. In order to model the economic incentives that might influence the individual's decision to retire early, we have projected earnings profiles for the individuals in the future and in the past. In order to compute each individual's pension wealth and its increments we needed to make assumptions on the possible age-earnings profiles. For the age-earnings profiles, we have used the 2003 wave of the annual Labor Force Survey conducted by Statistics Sweden and controlled for age, gender and occupation; the coefficients are presented in Appendix $3 .^{7}$

We projected the annual earnings, expressed in 2003 prices, for all the eligible individuals 15 years back in time and depending on their age at the time of the observation, also by the

\footnotetext{
6 'Strenuous' applies in this case to both physically demanding work and sedentary type of jobs that do not require qualifications.

${ }^{7}$ We have also performed the imputations for age squared; the earnings profile then indicated a decrease in earnings followed past one's $55^{\text {th }}$ birthday, and for our calculations we needed the past 15 years to have been among the best an individual has had.
} 
number of years till they turn 65 years. ${ }^{8}$ As we lack the actual working histories of the individuals in the sample, we have assumed that all have worked for at least 30 years and that their work characteristics have not changed over this time (i.e. the persons in the sample have been working with the same full- or part-time share at the same workplace with the same occupational status). As these assumptions are quite strong this likely causes the incentive measures to carry measurement errors.

In order to evaluate how the rules of the pension (occupational and public) system in Sweden affect the decision to enter phased retirement we have computed pension wealth of the individuals eligible to enter phased retirement and of those who have already chosen this option. An individual's pension wealth is the discounted expected flow of benefits a worker can expect upon making a given retirement choice. Formally, it is defined as:

$$
P W_{a}=\sum_{r=a+4}^{\max a g e} \beta^{r-a} \cdot B_{a, r} \cdot \pi(r \mid a)
$$

where $B_{a}$ is the annual old-age benefit expected by an individual of an actual age a if (s)he chooses the phased retirement option at an age $r>a$. The old-age benefit does not change once it is calculated. $\pi(\mathrm{r} \mid \mathrm{a})$ is the probability that an individual is alive at the age of making the decision, $r=\{a+4, a+4+1, \ldots$, max age $\}$, conditioned on being alive at his actual age a. $\beta$ is a subjective time discount factor in the interval $(0,1)$. So someone aged 61 , who goes into phased retirement at the same age will have a pension wealth of:

$$
P W_{61}=\beta^{4} B_{61,61} \pi(65 \mid 61)+\beta^{5} B_{61,61} \pi(66 \mid 61)+\ldots
$$

In the construction of this hypothetical variable, we have adopted a convention that an eligible individual can make his or her choice immediately, i.e. the pension wealth is evaluated at the current decision point.

If the pension wealth of going into phased retirement increases, the demand for all goods will go up, including leisure. Hence, the phased retirement option creates an income effect that is supposed to affect the choice of early retirement positively. However, many social security systems have rules which create incentives to postpone early retirement in order to create more pension wealth. Thus there is also a substitution effect present in delaying the choice of

\footnotetext{
${ }^{8}$ We have used 15 years as for the majority of the individuals the largest component of their old-age benefit will be comprised of the defined benefit PAYGO ATP-benefit described in Appendix 2.
} 
choosing early retirement. In order to evaluate this substitution effect, we have computed two incentive measures: benefit accrual and benefit peak value. The (one-year) benefit accrual is defined as the change in the pension wealth due to postponing a retirement option one additional year:

$$
A C C_{a}=\sum_{r=a+4}^{\max a g e} \beta^{r-a} B_{a+1, r} \pi(r \mid a)-\sum_{r=a+4}^{\max a g e} \beta^{r-a} B_{a, r} \pi(r \mid a)
$$

This measure captures short-term incentives in postponing a retirement option. As Coile and Gruber (2007) stress, an additional year of work causes an increment in the pension wealth for two reasons. Postponing the decision to go into phased retirement changes the pension wealth, but the decision to postpone this option causes the time when claiming benefits to be shortened. The net effect of an increment in pension wealth will hence vary among individuals as their preferences might vary.

The change in the pension wealth from postponing a decision by a year captures a short-term increment offered by the pension system. If we assume the individuals to be rational decision makers, we should expect that they will take into account not only the one-year accrual that a given decision generates, but rather the difference in making a decision today and all possible future dates. A second measure, aimed at evaluating the accrual over an entire choice set of pension wealth is called the peak value. ${ }^{9}$ The peak value is the maximum difference between the pension wealth expected with making the phased retirement choice today and the same choice in the future, bounded by the age of 64 years being the last possible decision point. Formally it is defined as:

$$
P V_{a}=\max _{a^{*} \in\{a, a+1, \ldots, 64\}}\left\{\sum_{r=a^{*}+4}^{\max \text { age }} \beta^{r-a} B_{a^{*}, r} \pi(r \mid a)-\sum_{r=a+4}^{\max \text { age }} \beta^{r-a} B_{a, r} \pi(r \mid a)\right\}
$$

The benefit computation was done by using the rules described in the earlier section. The subjective discount rate was set at 2 per cent, making $\beta \approx 0.98$. The survival probabilities were computed on the basis of the life-length tables from Statistics Sweden for the year 2005 and vary by gender. The calculation was done for each age, starting from the individual's current age, $a$ :

$$
\pi(r \mid a)=\frac{\pi(r)}{\pi(a)} \in[0,1], r>a
$$

\footnotetext{
${ }^{9}$ The peak value was first used by Coile and Gruber (2007).
} 
As our analysis will be constrained to deal with those who are eligible to apply for phased retirement and to those who have already chosen it, we compute pension wealth only for those groups. For the phased retirees, who have already made their choice, accrual and peak values are set to zero, as there is no postponing of the retirement choice. As the scope of phased retirement is in theory a continuous choice variable, we needed to make an assumption as to what extent the individuals consider taking out their phased retirement benefits. We have set this scope to equal 50 per cent, as this is the most popular choice among current phased retirees.

Table 5 below presents the summary statistics of pension wealth, pension wealth divided by the yearly income, peak value and accrual, also those divided by the income variable.

Table 5 Summary statistics regarding pension wealth, peak value and accrual

\begin{tabular}{llllllll}
\hline Variable & Mean & Sd & p50 & Min & Max & Range & N \\
\hline Pension Wealth & 2603124 & 1548467 & 2240965 & 0 & 12859165 & 12859165 & 832 \\
Pension Wealth/Earnings & 6.117 & 1.273 & 6.055 & 0 & 11.948 & 11.948 & 821 \\
Peak Value & 82120 & 63212 & 73427 & -146 & 251005 & 251151 & 832 \\
Peak Value/Earnings & .2666 & .2305 & .2136 & -.0002 & .9255 & .9257 & 821 \\
Accrual & 28211 & 18045 & 29208 & -146 & 64590 & 64736 & 832 \\
Accrual/Earnings & .0914 & .0681 & .0837 & -.0002 & .2475 & .2478 & 821 \\
\hline
\end{tabular}

Source: Calculations based on data for Stockholm University for 2003-2006.

We see that there is plenty of variation in the pension wealth among the individuals and that this also applies to the incentive measures. The graph below displays the mean pension wealth by each age category. We see that it increases on average up to 64 years of age and then decreases rapidly as at 65 there is no possibility of entering the phased retirement option. 


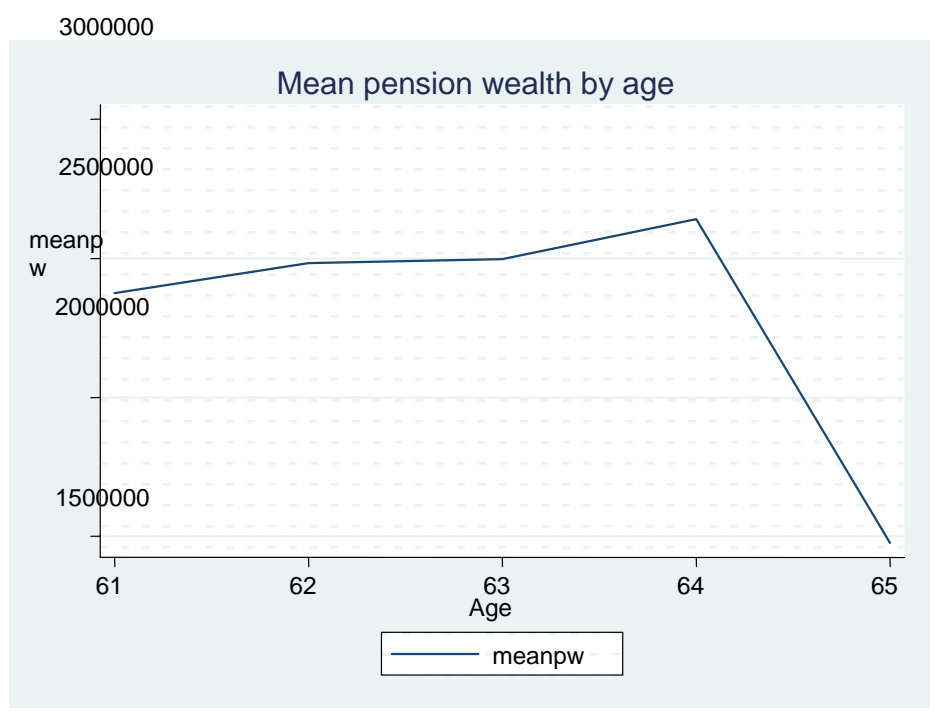

Figure 2 Mean pension wealth by age

\subsection{The variables for the financial situation of the department}

As we are able to identify the department that our individuals work at, we have been able to link it to variables indicating the financial situations of the departments. We have defined a measure of surplus for the department related to the total revenue of the department (grants from the university and from outside sources) over the accounting year. ${ }^{10}$ The higher this measure is, (the total margin) the better the financial situation of the department in question. This measure reflects the total capital gain after last years gain/loss has been added/deducted.

The second measure is the net margin in the year and does not consider the capital that is brought from the year previously. ${ }^{11}$ Hence it is a net margin. This measure reflects current profitability of a department better than the first measure ${ }^{12}$. Table 6 gives summary statistics from the balance sheets.

\footnotetext{
${ }^{10}$ Total margin $=(($ balance carried forward $) /($ total revenue $))=(($ total capital gain $) /($ total revenue $))$

${ }^{11}$ Net margin = (("balance carried forward"-"balance brought forward")/(total revenue $\left.)\right)($ (total capital gain-last year's capital gain $) /($ total revenue $))=(($ annual capital gain $) /($ total revenue $))$

${ }^{12}$ The correlation coefficient between eko and eko2 turned out to be 0.44
} 
Table 6 Summary Statistics of the Financial Variables

\begin{tabular}{lcllllll}
\hline Variable & Mean & Sd & p50 & Min & Max & Range & N \\
\hline $\begin{array}{l}\text { Phased or Eligible } \\
\text { Net margin }\end{array}$ & -.0065 & .0628 & $3.2 \mathrm{e}-04$ & -.4142 & .2340 & .6481 & 1139 \\
Total margin & .0438 & .1794 & .0565 & -.6299 & .8341 & 1.464 & 1139 \\
& & & & & & & \\
Phased & & & & & & & \\
Net margin & -.0101 & .0612 & -.0014 & -.3038 & .2340 & .5378 & 317 \\
Total margin & .0172 & .1753 & .0173 & -.6116 & .8341 & 1.446 & 317 \\
& & & & & & & \\
Eligible & & & & & & & \\
Net margin & -.0051 & .0633 & $3.2 \mathrm{e}-04$ & -.4142 & .2340 & .6481 & 822 \\
Total margin & .0541 & .1801 & .0696 & -.6299 & .8298 & 1.46 & 822 \\
\hline
\end{tabular}

Source: Calculations based on data for Stockholm University for 2003-2006.

Hence we see that net margin is negative for both the sample where we have eligible individuals and phased retirees and that for the latter it is smaller. We have restricted our sample by removing the observations for three administrative units as transfers dominate the accounts for those units.

\section{The Empirical Model}

The objective of our study is to establish correlations influencing the decision to enter the phased retirement program and we shall consider the data as consisting of person-year observations. Hence the full data set is a pooled cross-section of individuals at different points in time. For this we need to narrow our sample to include those individuals who are eligible to enter the phased retirement option. Hence the sample on which the regressions are performed includes those individuals who have chosen the phased retirement option and those who are between the ages of 61 and 65, are employed at Stockholm University, have not become retired in any of the forms described earlier and have working hours in proportion to full-time employment that is more than 50 per cent. Table 7 presents how many were eligible in each year to apply to the phased retirement option. 
Table 7 Number of employees eligible for applying for a part-time pension

\begin{tabular}{lc}
\hline Year & Number of eligible \\
\hline 2003 & 131 \\
2004 & 190 \\
2005 & 231 \\
2006 & 280 \\
\hline Total & 832 \\
\hline
\end{tabular}

Source: Calculations based on data for Stockholm University for 2003-2006.

Hence, together with the 322 phased retirees in the sample, we can use 1154 observations in the regressions.

In order to evaluate the incentives in the pension system on the probability of the individuals to choose phased retirement we include the variables pension wealth, accrual and peak value in the regression analysis. Following Coile and Gruber (2007) we can plausibly see two effects that the incentives of the pension system can have on the decision to go into phased retirement. One is an income effect: choosing phased retirement creates a stream of benefits that would not have been there otherwise and this can raise the demand for all goods, including leisure. A second effect is a substitution effect created by the increments in pension wealth by postponing one's decision. Postponing ones claims to the (phased) retirement benefits can increase the consumption when retired, through the accruals.

Further, the decision to go into phased retirement can be influenced by the aspects related to one's workplace. As the departments at Stockholm University have their own budgets and the decision to admit phased retirement (both at the extensive and intensive margin) is at the discretion of the employer, the level of the financial stability may influence the probability of an employee going into phased retirement. We have two variables at our disposal that indicate the financial performance of the institutions.

The econometric model we used is the basic linear probability model:

$$
\operatorname{Pr}(\text { Phased retirement }=1 \mid P W, I N C, \mathbf{x}, e k o)_{i t}=\alpha+\beta_{1} P W_{i t}+\beta_{2} I N C_{i t}+\mathbf{x}^{\prime} \boldsymbol{\beta}+F^{\prime} N_{i t-1}^{\prime} \theta+\varepsilon_{i t}
$$

Where the dependant variable is the probability that the individual $i$ at age $t$ has chosen the phased retirement option and zero otherwise. PW is the pension wealth variable, while INC is any of the two incentive measures described above (accrual or peak value). $\mathbf{x}$ is a vector of personal characteristics deemed to have an effect on the decision to enter the phased retirement program. The variables at our disposal that might influence the individual's choice 
are: age, gender, annual payments, type of work performed, form of employment, type of retirement agreement, place of employment and tenure.

Further, it is interesting to see whether the financial situation of the department might constitute a factor in the decision-making. Hence, $\mathrm{FIN}_{\mathrm{it}-1}$ is a polynomial function of the eko or eko2 variable. The hypothesis is that for $\mathrm{FIN}_{\mathrm{it}-1}=\mathrm{eko}_{\mathrm{it}-1}$, the coefficient ought to have a negative sign; a department whose financial situation is better might be inclined to be less supportive of its employees partially exiting into retirement. It is however quite possible that the relationship between the choice of gradually retiring and the eko variables is of a nonlinear. If $\mathrm{FIN}_{\mathrm{it}-1}=\mathrm{ekO}_{\mathrm{it}-1}+\mathrm{ekO}_{\mathrm{it}-1}{ }^{2}$ then the relationship is still presumed to be negative but could be of a decreasing or increasing nature.

There is also the issue of reverse causality. That is of the number of phased retirees affecting the finances of the institution. We try to omit this problem by always using a one-year lag in the FIN variables to the year in which the individual is observed.

\section{Estimation results}

The results from the econometric estimations are shown in Table 8 and 9 (these two tables are placed after the main text). In all of the regressions we have clustered the standard errors so as to account for that the same person can appear in the pooled OLS up to four times. Hence the standard errors have been clustered on the individual's identification number. We will make comments on the main results below.

The coefficient for the variable "woman" is positive meaning that women are more likely to become part-time pensioners. However, the values are not always significantly different from zero. The propensity to take a part-time pension increases by age - the closer to the normal retirement age of 65 the more likely it is that the employee is part-time pensioned. The propensity to become part-time pensioned was highest in 2003, the first year of the scheme. This may be explained by that a number of employees would have applied for a part-time pension earlier if it had been possible, applied as soon as it was possible to do so, i.e. in 2003. The number of years employed at the university however does not influence the probability to become a part-time pensioner but those with tenured employment are more likely to take up a part-time pension. Part-time pensions entail costs for the departments and it is likely that a department is more reluctant to accept an application from someone with temporary employment status. Those with higher earnings less often become a part-time pensioner. This 
is the case even if controlling for occupational status. An explanation for that higher earnings is combined with a lower propensity to take up a part-time pension could be that those who have higher earnings also have more interesting work tasks and therefore want to continue to work full-time. Among the occupational groups, professors and researchers are those who are least likely to take up a part-time pension.

For the pension variables we got the expected negative values for both benefit accrual (table 8) and peak value (table 9). The more the pension wealth increases if the employee works one year more (benefit accrual) and the higher the employee's peak of the pension wealth is year(s) ahead, the more likely it is that the employee will continue to work and not take up a part-time pension. Benefit accrual explains more of the variation in the propensity to take up a part-time pension than the peak value does. As expected pension wealth has a positive sign. It is highly significant in estimations including the peak value variable but not in those including the benefit accrual variable.

The financial situation of the department/unit is included in the estimations by both a linear and a quadratic term. The coefficients are both highly significant, the linear term with a negative sign and the quadratic with a positive sign. The relation is U-shaped. The part-time intensity is higher both among the units with a good financial status and those with a bad financial one compared to those in a middle group. The explanation for choosing the part-time solution can be different for units with a good and with a bad financial situation. For departments with a bad financial situation the part-time pension can be a cost-efficient way of reducing the personal costs compared to laying off persons. For departments with a good financial situation granting a part-time pension could be a method to reward employees - it costs but the department has resources for doing that. A method to further study this issue is to examine if the part-time pensions have the same scope at departments with a weak financial standing as at those with a strong financial standing. See Table 10. 
Table 10 Financial situation for the department/unit and scope of the part-time pensions

\begin{tabular}{llll} 
Scope & $\begin{array}{l}\text { Departments with } \\
\text { negative capital (1) }\end{array}$ & $\begin{array}{l}\text { Departments with a } \\
\text { small positive } \\
\text { capital compared to } \\
\text { their income (2) }\end{array}$ & $\begin{array}{l}\text { Departments with a } \\
\text { large positive } \\
\text { capital compared to } \\
\text { their income (3) }\end{array}$ \\
\hline $\mathbf{2 0} \%$ or less & $1(<1 \%)$ & $1(1 \%)$ & $0(0 \%)$ \\
$\mathbf{2 1 - 4 9} \%$ & $99(67 \%)$ & $47(55 \%)$ & $52(60 \%)$ \\
$\mathbf{5 0} \%$ & $48(33 \%)$ & $38(44 \%)$ & $35(40 \%)$ \\
\hline Total & $147(100 \%)$ & $86(100 \%)$ & $87(100 \%)$ \\
\hline
\end{tabular}

Note. The boundary between (2) and (3) is set so that the part-time pensioners in the two groups are equal; for (2) the economic margin is between 0 and 0.1 , and for (3) it is higher than 0.1 .

Source: Calculations based on data for Stockholm University for 2003-2006.

The table shows that there are some differences. Relatively fewer part-time pensioners have the highest possible part-time scope, i.e. 50 per cent, at the departments with a weak financial position.

\section{Summary and conclusion}

In 2003 a new part-time pension scheme was introduced in Sweden for state employees. Those aged 61-64 who met certain requirements could apply for a pension and the employer could accept or reject the application. If granted the employee received a compensation of 60 per cent of reduction in earnings.

We study this system at one state employer, Stockholm University, in 2003-2006. The focus of our interest are the factors that influence if an employee who is eligible for a part-time pension actually takes up a pension The outcome is dependent on both that the employee makes an application and that the employer approves it.

At Stockholm University the departments and other units on the same level decide themselves in practice if they should encourage applications and accept or reject them. The departments pay part of the pension costs but not all of them. The costs are partly covered by the central university administration.

The outcome is determined by actions from both the employee and the employer. In our estimations we have therefore included both variables that influence the decision to apply for 
the employee, and variables that influence the decision to accept an application by the employer.

As variables on the individual level, we have included individual characteristics and variables representing economic incentives to take up or not take up a part-time pension formed by the pension schemes (social security and supplementary). As variables on the employer side we have included a variable representing the economic situation of the department.

The main results regarding the individual characteristics are that the propensity to take up a part-time pension is higher among women than men, higher among those close to retirement age, lower among those with high earnings, and higher among professors/researchers than among categories of personnel.

We get the expected results regarding the pension variables. The higher the pension accrual (for waiting an extra year) and the higher the peak value of the pension wealth (compared to the present pension wealth), the lower is the propensity to take up a part-time pension. A higher pension wealth (compared to earnings) means a higher propensity to take up a pension. This variable is however not significant in all formulations of the model.

The estimations show that the take-up of part-time pensions is highest among the departments with the worst economic situation (a cost efficient method to reduce the personnel) and among the departments with the best economic situation (a way of rewarding employees). 
Table 8 Factors influencing part-time pension including pensions wealth and benefit accrual

\begin{tabular}{|c|c|c|c|c|}
\hline Variable & $(1)$ & $(2)$ & $(3)$ & $(4)$ \\
\hline Pension Wealth/Earnings & $\begin{array}{l}0.0104 \\
(0.82)\end{array}$ & $\begin{array}{l}0.00729 \\
(0.58)\end{array}$ & $\begin{array}{l}0.0156 \\
(1.31)\end{array}$ & $\begin{array}{l}0.0168 \\
(1.42)\end{array}$ \\
\hline Benefit Accrual/1000 & $\begin{array}{l}-0.0173 * * * \\
(-21.3)\end{array}$ & $\begin{array}{l}-0.0175^{* * *} \\
(-21.7)\end{array}$ & $\begin{array}{l}-0.0175 * * * \\
(-23.0)\end{array}$ & $\begin{array}{l}-0.0173 * * * \\
(-23.0)\end{array}$ \\
\hline Woman & $\begin{array}{l}0.0584 * * \\
(2.41)\end{array}$ & $\begin{array}{l}0.0553 * * \\
(2.30)\end{array}$ & $\begin{array}{l}0.0364 \\
(1.58)\end{array}$ & $\begin{array}{l}0.0435^{*} \\
(1.89)\end{array}$ \\
\hline 62 years & $\begin{array}{l}0.0309 * * \\
(2.37)\end{array}$ & $\begin{array}{l}0.0304^{* *} \\
(2.37)\end{array}$ & $\begin{array}{l}0.0246 * * \\
(1.97)\end{array}$ & $\begin{array}{l}0.0233^{*} \\
(1.86)\end{array}$ \\
\hline 63 years & $\begin{array}{l}0.0381^{* *} \\
(2.07)\end{array}$ & $\begin{array}{l}0.0415^{* *} \\
(2.27)\end{array}$ & $\begin{array}{l}0.0352^{* *} \\
(1.98)\end{array}$ & $\begin{array}{l}0.0337^{*} \\
(1.87)\end{array}$ \\
\hline 64 years & $\begin{array}{l}0.0538 * * \\
(2.08)\end{array}$ & $\begin{array}{l}0.0581 * * \\
(2.25)\end{array}$ & $\begin{array}{l}0.0506^{* *} \\
(2.02)\end{array}$ & $\begin{array}{l}0.0463^{*} \\
(1.83)\end{array}$ \\
\hline 65 years & $\begin{array}{l}0.125^{* * * *} \\
(2.80)\end{array}$ & $\begin{array}{l}0.130 * * * \\
(2.89)\end{array}$ & $\begin{array}{l}0.116^{* * *} \\
(2.54)\end{array}$ & $\begin{array}{l}0.103^{* *} \\
(2.18)\end{array}$ \\
\hline Earnings/10 000 & $\begin{array}{l}-0.0153 * * * \\
(-19.3)\end{array}$ & $\begin{array}{l}-0.0153 * * * \\
(-18.9)\end{array}$ & $\begin{array}{l}-0.0147 * * * \\
(-17.4)\end{array}$ & $\begin{array}{l}-0.0148 * * * \\
(-17.0)\end{array}$ \\
\hline Employment in years at SU & $\begin{array}{l}0.000956 \\
(1.05)\end{array}$ & $\begin{array}{l}0.000609 \\
(0.67)\end{array}$ & $\begin{array}{l}-0.000177 \\
(-0.20)\end{array}$ & $\begin{array}{l}-0.000650 \\
(-0.73)\end{array}$ \\
\hline year 2004 & $\begin{array}{l}-0.0371 * * \\
(-2.26)\end{array}$ & $\begin{array}{l}-0.0403^{* *} \\
(-2.48)\end{array}$ & $\begin{array}{l}-0.0416 * * * \\
(-2.64)\end{array}$ & $\begin{array}{l}-0.0383 * * \\
(-2.40)\end{array}$ \\
\hline year 2005 & $\begin{array}{l}-0.0323 \\
(-1.37)\end{array}$ & $\begin{array}{l}-0.0371 \\
(-1.59)\end{array}$ & $\begin{array}{l}-0.0317 \\
(-1.38)\end{array}$ & $\begin{array}{l}-0.0279 \\
(-1.21)\end{array}$ \\
\hline year 2006 & $\begin{array}{l}-0.152 * * * \\
(-5.67)\end{array}$ & $\begin{array}{l}-0.150 * * * \\
(-5.55)\end{array}$ & $\begin{array}{l}-0.200 * * * \\
(-6.52)\end{array}$ & $\begin{array}{l}-0.193 * * * \\
(-6.09)\end{array}$ \\
\hline Net margin & $\begin{array}{l}-0.182 * * * \\
(-3.74)\end{array}$ & $\begin{array}{l}-0.178 * * * \\
(-3.60)\end{array}$ & $\begin{array}{l}-0.118 * * \\
(-2.40)\end{array}$ & $\begin{array}{l}-0.0818 \\
(-1.29)\end{array}$ \\
\hline Net margin squared & $\begin{array}{l}0.212^{* *} \\
(2.25)\end{array}$ & $\begin{array}{l}0.207^{* *} \\
(2.20)\end{array}$ & $\begin{array}{l}0.165 * \\
(1.86)\end{array}$ & $\begin{array}{l}0.201^{* *} \\
(2.02)\end{array}$ \\
\hline Tenured employment & & $\begin{array}{l}0.176 * * \\
(2.47)\end{array}$ & $\begin{array}{l}0.194 * * * \\
(3.02)\end{array}$ & $\begin{array}{l}0.191 * * * \\
(3.02)\end{array}$ \\
\hline Strenuous work & & & $\begin{array}{l}0.0907 \\
(0.93)\end{array}$ & $\begin{array}{l}0.0818 \\
(0.84)\end{array}$ \\
\hline
\end{tabular}




\begin{tabular}{|c|c|c|c|c|}
\hline Lower Admin. Staff & & & $\begin{array}{l}0.101^{* *} \\
(2.26)\end{array}$ & $\begin{array}{l}0.0902^{* *} \\
(2.08)\end{array}$ \\
\hline Higher Admin. Staff & & & $\begin{array}{l}0.170^{* * *} \\
(6.07)\end{array}$ & $\begin{array}{l}0.172^{* * *} \\
(6.12)\end{array}$ \\
\hline Lecturer & & & $\begin{array}{l}0.183^{* * *} \\
(5.91)\end{array}$ & $\begin{array}{l}0.197 * * * \\
(6.35)\end{array}$ \\
\hline Administration & & & & $\begin{array}{l}0.0451 \\
(0.93)\end{array}$ \\
\hline Humanities & & & & $\begin{array}{l}-0.0513 * \\
(-1.72)\end{array}$ \\
\hline Law School & & & & $\begin{array}{l}-0.00349 \\
(-0.073)\end{array}$ \\
\hline Natural Sciences & & & & $\begin{array}{l}0.0374 \\
(1.43)\end{array}$ \\
\hline Library & & & & $\begin{array}{l}-0.0232 \\
(-0.61)\end{array}$ \\
\hline Constant & $\begin{array}{l}1.128^{* * *} \\
(10.2)\end{array}$ & $\begin{array}{l}0.991 * * * \\
(8.00)\end{array}$ & $\begin{array}{l}0.824 * * * \\
(6.75)\end{array}$ & $\begin{array}{l}0.818^{* * *} \\
(6.72)\end{array}$ \\
\hline Observations & 1127 & 1127 & 1127 & 1127 \\
\hline Adjusted R-squared & 0.71 & 0.72 & 0.74 & 0.74 \\
\hline $\mathrm{F}$ & 201.0 & 189.8 & 145.1 & 116.7 \\
\hline
\end{tabular}


Table 9 Factors influencing part-time pension including pensions wealth and peak value

\begin{tabular}{|c|c|c|c|c|}
\hline Variable & $(1)$ & $(2)$ & $(3)$ & (4) \\
\hline Pension wealth/Earnings & $\begin{array}{l}0.0338 * * * \\
(2.77)\end{array}$ & $\begin{array}{l}0.0315 * * * \\
(2.64)\end{array}$ & $\begin{array}{l}0.0396 * * * \\
(3.40)\end{array}$ & $\begin{array}{l}0.0410 * * * \\
(3.58)\end{array}$ \\
\hline Peak Value/1000 & $\begin{array}{l}-0.00512^{* * *} \\
(-19.4)\end{array}$ & $\begin{array}{l}-0.00517 * * * \\
(-19.8)\end{array}$ & $\begin{array}{l}-0.00517^{* * *} \\
(-20.8)\end{array}$ & $\begin{array}{l}-0.00510 * * * \\
(-21.1)\end{array}$ \\
\hline Woman & $\begin{array}{l}0.0447^{*} \\
(1.71)\end{array}$ & $\begin{array}{l}0.0421 \\
(1.62)\end{array}$ & $\begin{array}{l}0.0205 \\
(0.82)\end{array}$ & $\begin{array}{l}0.0300 \\
(1.22)\end{array}$ \\
\hline 62 years & $\begin{array}{l}-0.0945 * * * \\
(-6.91)\end{array}$ & $\begin{array}{l}-0.0959 * * * \\
(-7.16)\end{array}$ & $\begin{array}{l}-0.102^{* * *} \\
(-7.80)\end{array}$ & $\begin{array}{l}-0.102 * * * \\
(-7.88)\end{array}$ \\
\hline 63 years & $\begin{array}{l}-0.194^{* * *} \\
(-8.80)\end{array}$ & $\begin{array}{l}-0.193 * * * \\
(-8.82)\end{array}$ & $\begin{array}{l}-0.199 * * * \\
(-9.28)\end{array}$ & $\begin{array}{l}-0.198 * * * \\
(-9.34)\end{array}$ \\
\hline 64 years & $\begin{array}{l}-0.253 * * * \\
(-7.51)\end{array}$ & $\begin{array}{l}-0.252 * * * \\
(-7.50)\end{array}$ & $\begin{array}{l}-0.258 * * * \\
(-7.92)\end{array}$ & $\begin{array}{l}-0.260 * * * \\
(-8.07)\end{array}$ \\
\hline 65 years & $\begin{array}{l}0.0124 \\
(0.25)\end{array}$ & $\begin{array}{l}0.0155 \\
(0.32)\end{array}$ & $\begin{array}{l}0.00273 \\
(0.054)\end{array}$ & $\begin{array}{l}-0.0165 \\
(-0.32)\end{array}$ \\
\hline Earnings/10 000 & $\begin{array}{l}-0.0159 * * * \\
(-19.6)\end{array}$ & $\begin{array}{l}-0.0159 * * * \\
(-19.3)\end{array}$ & $\begin{array}{l}-0.0154 * * * \\
(-17.4)\end{array}$ & $\begin{array}{l}-0.0155 * * * \\
(-17.3)\end{array}$ \\
\hline Employment in years at SU & $\begin{array}{l}0.00159 \\
(1.63)\end{array}$ & $\begin{array}{l}0.00132 \\
(1.34)\end{array}$ & $\begin{array}{l}0.000558 \\
(0.58)\end{array}$ & $\begin{array}{l}-0.0000677 \\
(-0.071)\end{array}$ \\
\hline year 2004 & $\begin{array}{l}-0.0306 \\
(-1.56)\end{array}$ & $\begin{array}{l}-0.0331^{*} \\
(-1.69)\end{array}$ & $\begin{array}{l}-0.0347 * \\
(-1.82)\end{array}$ & $\begin{array}{l}-0.0299 \\
(-1.56)\end{array}$ \\
\hline year 2005 & $\begin{array}{l}-0.0151 \\
(-0.57)\end{array}$ & $\begin{array}{l}-0.0189 \\
(-0.72)\end{array}$ & $\begin{array}{l}-0.0140 \\
(-0.54)\end{array}$ & $\begin{array}{l}-0.00875 \\
(-0.33)\end{array}$ \\
\hline year 2006 & $\begin{array}{l}-0.122 * * * \\
(-4.18)\end{array}$ & $\begin{array}{l}-0.120 * * * \\
(-4.08)\end{array}$ & $\begin{array}{l}-0.180 * * * \\
(-5.45)\end{array}$ & $\begin{array}{l}-0.170 * * * \\
(-5.12)\end{array}$ \\
\hline Net margin & $\begin{array}{l}-0.182 * * * \\
(-3.35)\end{array}$ & $\begin{array}{l}-0.178^{* * *} \\
(-3.26)\end{array}$ & $\begin{array}{l}-0.112^{* *} \\
(-2.05)\end{array}$ & $\begin{array}{l}-0.0617 \\
(-0.90)\end{array}$ \\
\hline Net margin squared & $\begin{array}{l}0.222^{* *} \\
(2.17)\end{array}$ & $\begin{array}{l}0.218^{* *} \\
(2.13)\end{array}$ & $\begin{array}{l}0.167 * \\
(1.75)\end{array}$ & $\begin{array}{l}0.199 * \\
(1.84)\end{array}$ \\
\hline Tenured employment & & $\begin{array}{l}0.144 * \\
(1.86)\end{array}$ & $\begin{array}{l}0.163^{* *} \\
(2.33)\end{array}$ & $\begin{array}{l}0.163^{* * *} \\
(2.34)\end{array}$ \\
\hline Strenuous work & & & $\begin{array}{l}0.0690 \\
(0.55)\end{array}$ & $\begin{array}{l}0.0597 \\
(0.49)\end{array}$ \\
\hline
\end{tabular}




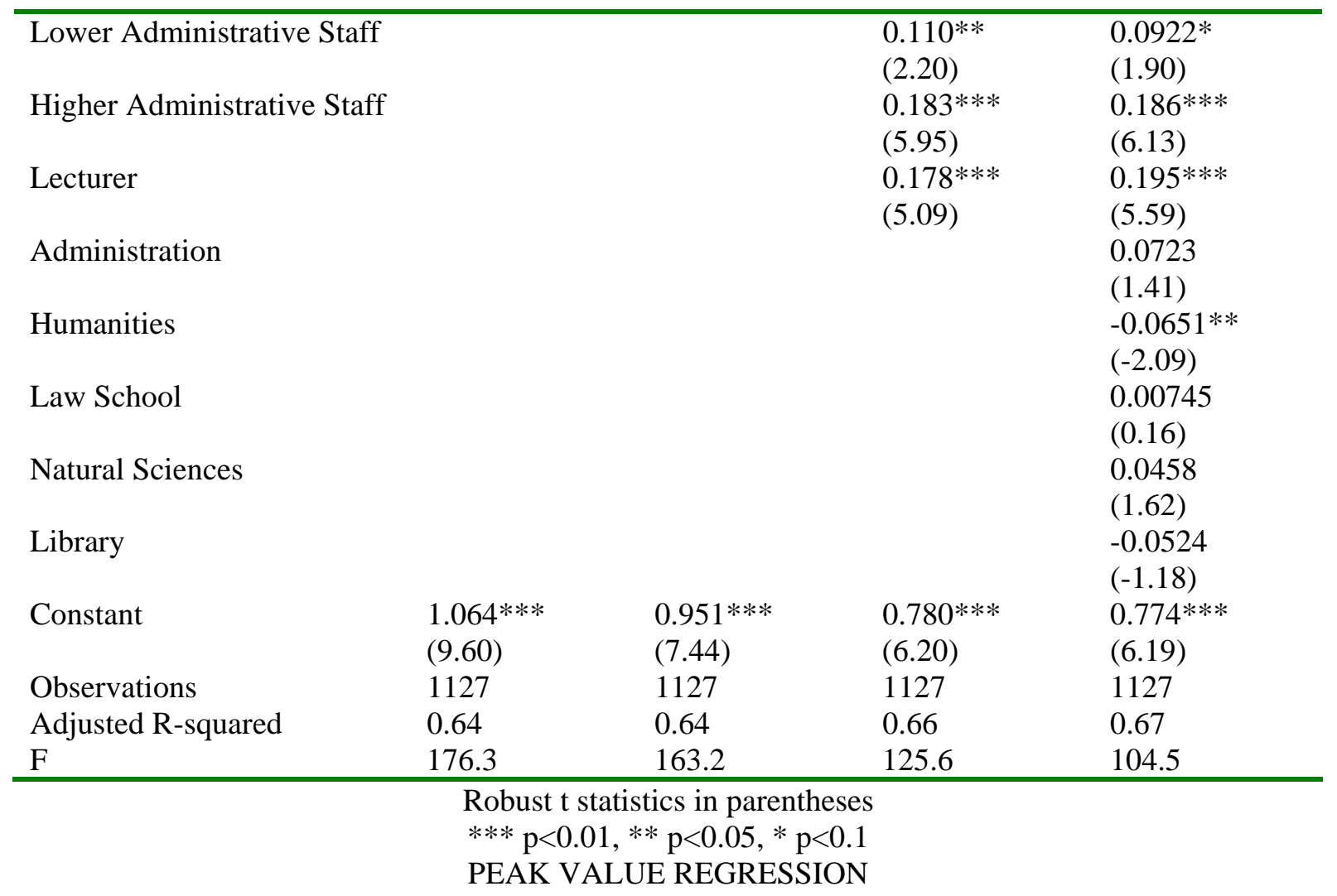




\section{References}

Allen, Steven G. (2004), “The Value of Phased Retirement”, NBER Working Paper 10531.

Allen, Steven G., Clark, Robert L. and Ghent, Linda S. (2004), "Phasing into Retirement”, Industrial and Labor Relations Review, Vol. 58, 112-127.

Arbetsgivarverket (2002), ”Avtal om delpension - kommentarer”.

Chen, Yung-Ping (2004), “Report on Phased Retirement for the AARP”, June 30.

Chen, Yung-Ping and Scott, John C. (2003), "Gradual Retirement: An Additional Option in Work and Retirement”, North American Actuarial Journal, Vol. 7, no. 3, 62-74.

Chen, Yung-Ping and Scott, John C. (2006), "Phased Retirement: Who Opts for It and Toward What End?” Report to AARP 2006:1.

Clark, Denise M. (2002), “The Role of Multiemployer Defined Benefit Plans in an Era of

Phased Retirement”, Retirement Implications of Demographic and Family Change

Symposium, San Francisco, June 2002.

Coile, Courtney and Gruber, Jonathan (2007), "Future Social Security Entitlements and the Retirement Decision”, Review of Economics and Statistics, Vol. 89, no. 2, 234-246.

Delsen, Lei and Reday-Mulvey, Geneviève (eds.) (1996), Gradual Retirement in the OECD Countries, Aldershot: Dartmouth.

Even, William E. and Macpherson, David A. (2004), “Do Pensions Impede Phased Retirement?” IZA DP no. 1353.

Ginsburgh, Helen (1985), “Flexible and partial retirement for Norwegian and Swedish workers”, Monthly Labor Review, Vol. 108, no. 10, 33-43.

Gustman, Alan L. and Steinmeier, Thomas L. (1984), "Partial Retirement and the Analysis of Retirement Behavior”, Industrial and Labor Relations Review, Vol. 37, 403-415.

Kantarci, Tunga and Arthur van Soest (2008), “Gradual retirement: Preferences and limitations”, De Economist, Vol. 156, 113-144.

Lachowska, Marta, Sundén, Annika and Wadensjö, Eskil 2008, ”Delpension - ett sätt att öka arbetsutbudet bland äldre?” in Laura Hartman (ed.), Välfärd på deltid, SNS förlag, Stockholm.

Latulippe, Denis and Turner, John (2000), "Partial Retirement and Pension Policy in Industrialized Countries”, International Labour Review, Vol. 138, 179-195.

Mårtensson, Harald (2005), “Tillämpningen av det statliga kollektivavtalet om delpension”, SACO-S, 2005-08-17.

Nyman, Kjell and Valck, Lizbeth (2006), Tidiga pensionsavgångar från statliga myndigheter, Rapport till ESS 2006:1.

OECD (2007), Employment Outlook, Paris: OECD.

Penner, Rudolph G., Perun, Pamela and Steuerle, Eugene (2002), “Legal and Institutional Impediments to Partial Retirement and Part-time Work by Older Workers”, Washington DC: The Urban Institute.

Scahill, Patricia L. and Forman, Jonathan Barry (2002), "Protecting Participants and Beneficiaries in a Phased Retirement World”, Retirement Implications of Demographic and Family Change Symposium, San Francisco, June 2002. 
Statistics Sweden, Labour Force Surveys.

Sundén, Annika (1994), Early Retirement in the Swedish Pension System, PhD thesis, Ithaca: Cornell University.

Wadensjö, Eskil (1991), “Partial Exit: Sweden”, in Martin Kohli, Martin Rein, Anne Marie Guillemard and Hermann van Gunsteren, (eds.), Time for Retirement: Comparative studies of early exit from the labor force, Cambridge: Cambridge University Press.

Wadensjö, Eskil (1993), "Partial Exit Options in Sweden: Recent and Future Changes”, Generations, Vol. 17, no. 4, 15-19.

Wadensjö, Eskil (1996), “Gradual Retirement in Sweden” in Lei Delsen and Geneviève Reday-Mulvey (eds.), Gradual Retirement in the OECD Countries, Aldershot: Dartmouth.

Wadensjö, Eskil (2003),“Deltidspension - Ett sätt att höja antalet arbetade timmar i ekonomin?”, Arbetsliv och samhälle, supplement B to SOU 2003:91.

Wadensjö, Eskil (2006a), “Part-time pensions and part-time work in Sweden”, IZA DP no. 2273.

Wadensjö, Eskil (2006b), “Part-Time Pensions and Part-Time Work in Sweden”, European Papers on the New Welfare, (6), 29-45.

Wadensjö, Eskil and Sjögren, Gabriella (2000), Arbetslinjen för äldre i praktiken. En rapport för Riksdagens revisorer, Stockholm: Swedish Institute for Social Research.

Wise, Lois (1990), “Partial and Flexible Retirement: The Swedish System”, The Gerontologist, Vol. 30, 355-361.

Wong, Aliya (2002), “Defined Benefit Plans in an Era of Phased Retirement”, "Protecting Participants and Beneficiaries in a Phased Retirement World”, Retirement Implications of Demographic and Family Change Symposium, San Francisco, June 2002. 


\section{Appendix 1: The variables}

This appendix describes the variables used in this analysis.

\section{Individual characteristics}

- woman: indicator of gender.

- age: age of the individual

- anstform: Indicator of form of employment. There are two categories in the data set: an open-ended contract or a temporary employment.

- befattning: title of position held at Stockholm University. In the data set there were 57 different categories. The variable that codes those different categories is befkod.

- arb: variable created from aggregating "befattning” to six categories: strenuous work, lower administrative personnel, higher administrative personnel, researcher, lecturer and professor.

- slutsorsak: reason for exiting employment at a specific position at Stockholm University. There are thirteen possibilities. Those categories are lack of work, change of position within one's department, county council, private sector employment, state sector employment, termination of temporary employment, change of employment to other university, old-age pension, early old-age pension, supplementary pension, disability pension, and other or unknown reasons. The variable that codes the different categories is slutorsak.

- anst2: An indicator of when a person is employed at Stockholm University. It is logically fulfilled if the individual's slutorsak is either change of position within one's department or none of the other definitions of slutorsak.

- syss_grad: working hours as part of full-time employment.

- anstdatsu: date of starting employment at Stockholm University.

- anstdatstat: date of starting employment in the state sector.

- ansttid 0604: tenure as of end of March 2006.

- lengthsu: created from ansttid 0604 to specify duration of position held.

- institution: indicator of department affiliation ${ }^{13}$. The variable is more specific than the name suggests, as it also specifies different sub-sections of departments and other administrative units. The variable that codes department affiliation, on department level only is orghem.

- fakultet: Indicator of in which faculty the individual is employed. There are four faculties at Stockholm University: Law, Humanities, Social Sciences and Natural Sciences. The variable also includes two units that are not faculties: the Stockholm University Library and the Administration.

- utbet: annual payment (net of taxes) utbet_tsn is defined as utbet/10000 and adjusted for CPI with 2003 being the base year.

- avtal: pension agreement. There are two agreements in the data set: A01 and C01.

- omf: phased retirement as a part of full-time employment.

- delp: indicator variable of participation in the phased retirement program.

\footnotetext{
${ }^{13}$ In general, the label 'department' will be used to apply to all forms of university institutions at the same administrative level.
} 
- eligible_ind: a created variable indicating whether the individual at a given year is eligible to apply to the phased retirement program. The indicator is logically fulfilled if the individual is older than 60 , but younger than 65 , working hours as part of fulltime are $>50$ per cent, the person in question if employed as defined by ans2, not retired as defined by retired and has not chosen the phased retirement option as defined by delp.

\section{Financial characteristics of the departments or other Stockholm University institutions}

- oms: total revenue. oms_ttsn is defined as oms/10000 and adjusted for CPI with the year 2003 as base.

- kap: annual capital gain. kap_ttsn is defined as kap/10000 and adjusted for CPI with the year 2003 as base.

- ib: balance brought forward. ib_ttsn is defined as ib/10000 and adjusted for CPI with the year 2003 as base.

- ub: balance carried forward. ub_ttsn is defined as ub/10000 and adjusted for CPI with the year 2003 as base.

- eko: a created rate of return variable. See $(<\mathrm{ref}>\mathrm{eko} 2.2</ \mathrm{ref}>)$.

- eko2: a created rate of return variable See $(<$ ref $>$ eko $2</$ ref $>)$.

- index: CPI; year 2003 is the base year. 


\section{Appendix 2: Computation of pension benefits:}

All the values are expressed in the year 2003 values. The following values for the basic amounts are used: Basic Amount $(B A)=38$ 600, Income Basic Amounts (IBA) $=40$ 900, Increased Basic amounts (IncBA) $=39400$.

\section{The public pension system}

Upon retirement the individuals in our dataset will be subject to the rules governing the prereformed Swedish public pension system and the new one. Depending on the individual's year of birth, different weight will be attached to how large of a share comes from the new pension system and how large fro the old.

The pre-reform pension system consisted of a flat benefit part and a defined benefit PAYGO part (called the ATP), where one's old age pension was computed on the basis of one's 15 best years out of 30, up to a ceiling governed by 7.5 Income Basic Amounts (IBA). The benefit was computed according to:

$$
A T P_{i t}=0.6 \times A P_{i} \times \min \left\{\frac{N_{i}}{30}, 1\right\} \times I B A_{t}
$$

Where $N_{i}$ was the number of years working, $A P_{i}$ is the average pension points calculated as:

$$
A P_{i}=\frac{\max _{t=1, \ldots, 15}\left\{\sum_{t=1}^{N_{i}} \text { pension rights income }{ }_{\mathrm{i}, \mathrm{t}}-I B A_{t}\right\}}{I B A_{t}}
$$

where the pension rights income falls in the range between one IBA and 7.5 IBA. For our calculations we have taken the pension rights income to be the annual salary paid and assumed that $N_{i}=30$ for all.

The flat rate benefit is computed as $F P_{i t}=0.96 \times B A_{t}$, where BA is the Basic Amount (BA).

The reformed pension system consists of the three parts: an income-based pension, a fully funded part and a guarantee pension. We have only used the first one in our computations. The income pension (IP) was computed according to the following:

pension rights income $\mathrm{i}_{\mathrm{i}, \mathrm{t}}=0.185 \times \min \left\{\right.$ income $\left._{\mathrm{it}}, 7.5 \operatorname{IncBA}_{t}\right\}$ 
where the pension rights income is at most 18.5 per cent of the Increased Basic Amount (IncBA). ${ }^{14}$

$$
I P_{i}=\frac{\left\{\sum_{s=\text { retirementage-1 }}^{N_{i}} \text { pension rights income }{ }_{\mathrm{i}, \mathrm{t}}\right\}}{\text { divisor }_{\mathrm{t}}}
$$

The divisor is a gender neutral actuarial constant set annually by the Swedish Social Insurance Agency and varies for different cohorts and retirement years. For the years after retirement, the income pension is corrected by the growth rate of the economy (set to be 1.6 per cent annually):

$$
I P_{i, t+1}=\frac{I P_{i, t}}{1.016}
$$

Finally, the total benefit was computed as

$$
\text { Benefit }_{i, t}=\frac{\alpha}{20}\left[F P_{t}+A T P_{i, t}\right]+\frac{1-\alpha}{20} I P_{i, t}
$$

where $\alpha$ is a weight stemming from the cohort an individual belongs to, see the Table below for the different weights:

\begin{tabular}{ll}
\hline Cohort & $\boldsymbol{A}$ \\
\hline 1938 & 16 \\
1939 & 15 \\
1940 & 14 \\
$\cdots$ & $\cdots$ \\
\hline 1953 & 1 \\
\hline
\end{tabular}

\section{Occupational pensions}

There are two occupational pension plans used in our calculations for the government workers, PA 1991 and PA 2003. Both plans are comprised of several components, where the largest one is a PAYGO defined benefit plan based on a percentage of the average of the last five years of the worker's salary. The difference between the plans that used in this study is in that the PA 1991 uses the IBA as its base amount and that the replacement rates are constant for all in the span 1938-1942.

\footnotetext{
${ }^{14}$ In actuality only 16 per cent of the pension rights income is put in the notional account of the individual. The remaining 2.5 per cent is the premium pension. As we do not have the data on this, we implicitly assume that the fully funded part has the same return as the income pension.
} 


\begin{tabular}{|c|c|c|c|}
\hline Cohort & $\begin{array}{l}\text { Earnings } \in \\
\text { IncBA-7.5IncBA }\end{array}$ & $\begin{array}{l}\text { Earnings } \in \\
\text { 7.5IncBA-20IncBA }\end{array}$ & $\begin{array}{l}\text { Earnings } \in \\
\text { 20IncBA-30IncBA }\end{array}$ \\
\hline $1938-1942$ & $0.1 \cdot$ salary $^{*}$ & $0.65 \cdot\left(\right.$ salary-7.5IBA) ${ }^{*}$ & $\begin{array}{l}0.325 \cdot(\text { salary-20IBA })^{+} \\
0.65 \cdot(\text { salary-7.5IBA })^{*}\end{array}$ \\
\hline 1943 & 0.095 salary & $0.6485 \cdot($ salary-7.5IncBA) & $\begin{array}{l}0.324 \cdot(\text { salary-20IncBA })+ \\
0.6485 \cdot(\text { salary-7.5IncBA })\end{array}$ \\
\hline 1944 & $0.093 \cdot$ salary & $0.647 \cdot($ salary-7.5IncBA) & $\begin{array}{l}0.323 \cdot(\text { salary-20IncBA })+ \\
0.647 \cdot(\text { salary-7.5IncBA }\end{array}$ \\
\hline 1945 & 0.091·salary & $0.6455 \cdot($ salary-7.5IncBA) & $\begin{array}{l}0.322 \cdot(\text { salary-20IncBA })+ \\
0.6455 \cdot(\text { salary-7.5IncBA })\end{array}$ \\
\hline
\end{tabular}

The table below shows the different percentages, based on the level of the last five years of earnings. Hence if the average of the last five years earnings of a person born before 1943 falls between one IncBA and 7.5 IncBA's then the pension benefit will be 10 per cent of that salary. Similarly if such a person earns in the middle category, (s)he will get 65 per cent of what is above the 7.5 of the basic amounts.

\section{Pension wealth}

The pension wealth variable is calculated by summing up the benefits from the public pension system and the occupational pensions. Hence at each of the ages of the eligible persons we calculate what the individual can expect to receive starting from the age of 65 from the oldage pension and the occupational pension. From there we get the accrual measure and the peak value measure.

For the people who have already chosen phased retirement we assume that they will continue with it until their retirement at 65 years of age. These individuals have the accrual and peak value equal to zero as they cannot postpone their decision. 


\section{Appendix 3: Imputations from the Labor Force Surveys}

Below follow the coefficients from the Labor Force Survey 2003 regression. The dependent variable is the sum of the monthly earnings of the individuals employed in the public sector. The earnings were then multiplied by 12 to make them annual.

The 'working category' variables are created from the socioeconomic indicator variable, HUSEI. The category physically demanding work was taken from the category ' unskilled worker' (SEI code 1-22), the category 'blue collar worker' was taken from the SEI codes 33-46, 'white collar worker' was taken from SEI 50 and 'white collar worker, higher level' was taken from the category 56 and 57.

\begin{tabular}{|c|c|c|}
\hline & (1) & (2) \\
\hline COEFFICIENT & Earnings & $\ln$ (Earnings) \\
\hline Age & $\begin{array}{c}1619 * * * \\
(20.2)\end{array}$ & $\begin{array}{l}0.00469 * * * \\
\quad(21.0)\end{array}$ \\
\hline Woman & $\begin{array}{c}- \\
42390 * * * \\
(-23.8)\end{array}$ & $\begin{array}{c}-0.137 * * * \\
(-27.6)\end{array}$ \\
\hline Blue collar worker & $\begin{array}{c}34254^{* * *} \\
(9.82)\end{array}$ & $\begin{array}{c}0.130 * * * \\
(13.4)\end{array}$ \\
\hline White collar worker & $\begin{array}{l}94241 * * * \\
(25.8)\end{array}$ & $\begin{array}{c}0.313^{* * *} \\
(30.8)\end{array}$ \\
\hline $\begin{array}{l}\text { White collar worker, higher } \\
\text { level }\end{array}$ & $\begin{array}{c}157263^{* *} \\
*\end{array}$ & $0.484 * * *$ \\
\hline Constant & $\begin{array}{c}(33.3) \\
188100 * * \\
* \\
(40.0)\end{array}$ & $\begin{array}{c}(36.9) \\
12.22 * * * \\
(935)\end{array}$ \\
\hline Observations & 8224 & 8224 \\
\hline Adjusted R-squared & 0.28 & 0.32 \\
\hline $\mathrm{F}$ & 634.6 & 762.1 \\
\hline
\end{tabular}

